\title{
Evolving Medusa
}

\author{
Miguel Ángel Medina ${ }^{1}$
}

\begin{abstract}
This essay describes a proposed framework to better understand the artistic production of Pablo Picasso in the not well known period between two masterpieces, namely, The Three Dancers (1925) and Crucifixion (1930).
\end{abstract}

\section{Introduction}

The overwhelming artistic attraction of Florence was even increased in the turn from 2014 to 2015 with the great exhibition Picasso and Spanish Modernity at the Palazzo Strozzi, showing some ninety works by Picasso and other Spanish artists, ranging from painting to sculpture, drawing, engraving and even film, thanks to the new joint venture of Fondazione Palazzo Strozzi and the Museo Nacional Centro de Arte Reina Sofía in Madrid. This is somehow a natural sequel after the success of the previous exhibition Picasso, Miró, Dalí. Angry Young Men: the birth of Modernity, which took place at the Palazzo Strozzi between March $12^{\text {th }}$ and July $17^{\text {th }}$, 2011. Eugenio Carmona was co-curator (with Christoph Vitali) of that previous exhibition and is also the curator of Picasso and Spanish Modernity. Eugenio Carmona is full professor of Arts History at the University of Málaga and is currently one of the leading experts on the huge artistic work of Picasso. In his extensive academic work, Professor Carmona has devoted many studies to different aspects of the Picassian artistic work. Although Picasso is one of the artists with more studies, monographies, and articles devoted to his art, most of this bibliography turns around the best known topics, leaving in the shadow most of his production during the second part of his life. Perhaps the most relevant academic contributions made by Eugenio Carmona are related to his efforts to make understandable some dark periods in the artistic production of Picasso. This is the case of his proposed framework to better understand the Piccasian artistic production in the period 1926-1929 through what Professor Carmona calls the iconographies of disquietude (Carmona, 1994, 2002). The aim of this essay is to review this framework and the evolving meanings of these iconographies of disquietude.

\section{Source of images}

The special difficulties to freely reproduce artistic works by Picasso due to the copyright restrictions imposed by the Picasso family preclude this academic essay to be illustrated. However, throughout the text a number of Picasso's artistic works will be mentioned. To make them easily available to the interested readers, I will provide for each piece of work mentioned its reference in the On-line Picasso Project (MAllen, 1997-2016), the digital catalogue raisonné

${ }^{1}$ Miguel Ángel Medina is a Doctor in Biology and a Graduate in History of Arts currently working as Full Professor of Biochemistry and Molecular Biology at the University of Málaga (Spain).

Email: medina@uma.es 
described by its General Editor, Prof. Dr. Enrique Mallen as "the most comprehensive, authoritative and interactive resource on the life and works of Pablo Ruiz Picasso". This digital resource is maintained since 1997 by the Sam Houston State University and can be freely accessed (only for academic, no-profit use) by those who previously request an username and password. The references for each piece of work are of the type yoppXY-ABC, where $X Y$ are the two last figures of the year in which the piece of work was created and $A B C$ is a number with three figures indicating the order in which this piece of work appears in the folder correspondig to this year in the database.

\section{Context}

The masterpiece The Three Dancers (yopp25-001) is frequently referred as a turnaround after the so-called classical period. However, according to Prof. Carmona there is not such a radical disruption. Indeed, there are hints pointing to the fact that Picasso had begun to change his style at least from 1923 due to the exhaustion of the dialectical relationship between cubism and classicism. Furthermore, this change in style occurred while Picasso was able to continue moving between different registers. This is a key thesis revealed by Prof. Carmona: "the almost contradictory multiplicity was always a Picassian feature and it used to become even more notorious in transition moments". To illustrate this, a few months separate the moment of creation of the series of dots-and-lines drawings (see for instance yopp24-070) used several years after for the illustrated centennial edition of Le Chef d'oeuvre inconnu (1931) by Honoré de Balzac (1831), from that of the "classical" Mother and Son (1925, see yopp25-045) and that of the "cubist" The Drawing Lesson (1925, see yopp25-0o9).

In 1924, Picasso makes use for the first time of the illuminating iconographic resource of the unfolded faces. This is well illustrated by the painting Portrait of a Lassie with a String of Beds (1924, yopp24-115). This is not at all an exclusive Picassian iconographic resource, since other artists made use of it. This is the case of two members of the Spanish Generation of '27, namely, Federico García Lorca (author of the famous drawing Clown with Unfolded Face, 1927) and José Moreno Villa (author of the painting Heads (Lovers), 1929). Unfolded faces were sometimes painted by the surrealist Salvador Dalí (for instance, in his oil painting Three-fold Unfolding SelfPortrait, 1927).

A second iconographic resource widely used by Picasso in this period is that of the shadow profile, which already can be observed in The Three Dancers. The shadow profiles have been previously discussed by Victor Stoichita in the monography A Brief History of the Shadow (Stoichita, 1999).

Nonetheless, the most characteristic iconographic variable for this unquiet period appears in 1927 during the summer stay of Picasso in Cannes. Prof. Carmona narrates the emergence of this iconotype as follows:

"In 1927 (...) during the summer months in Cannes, (Picasso) drew strange anthropomorphic beings with dense and sometimes swollen members with sculptural qualities of stone and -to a lesser extent- of bone. In most of them (...), it is possible to discover concatenated allusions to signs of both sexes. The next year (...), he would model in plaster (...) figures translating to three dimension what had been elaborated in the Cannes drawings. During his summer holiday in Dinard, Picasso painted (...) youngs at the seashore or playing on the sand (...), 
nudes, with their sex very marked. The anatomy of these figures reduces the body to the form of pebbles and their textures imitated qualities of stone". ${ }^{2}$

These artworks have received the generic title of Baigneuse(s), that is, "Bather(s)", some of them with the added subtitle of Metamorphosis. This, Metamorphosis, is also the title of a masterpiece of literature written by Ovid, containing plentiful descriptions of mythological transformations. Mythological references are frequent throughout the artistic work of Picasso. For instance, in 1906 he painted a Dryad in a pre-cubist style, a painting extensively commented by Valeriano Bozal elsewhere (Bozal, 2002). This is also the case of Minotauromachy (1935), one of the masterpieces of engraving. Prof. Carmona reminds us that one of the transformations reported in Ovid's Metamorphosis is that of petrification, linked to the myth of the Gorgon Medusa. For this reason, Prof. Carmona proposes to call these Picassian petrified figures Medusa, which would be massive and $3 \mathrm{D}$ variants and evolutions of a much more schematic iconotype that appears recurrently in the artistic work of Picasso up to 1937, mainly in the period between 1927 and 1929. Of course, these are not arquetypal Medusas provided with her mane of snakes. In contrast, the Picassian Medusa provokes a deep disquiet. Some have tried to identify it with the outrageous image of Olga Koklova possessed by jealousy. For instance, this is the interpretation provided by the seventh chapter (entitled Dream and Nightmare) of the tutorial edited by Museum Thyssen-Bornemisza (Madrid, Spain) on The Mirror and the Mask. Portraiture in the Century of Picasso (Moreno, 2007) with regards to a picture showing evolved Picassian Medusa (see yopp28-0o6). In contrast with the "conventional" interpretation, Prof. Carmona offers convincing arguments in support of an alternative explanation: this iconotype could have emerged from the unfolding of a face related to the physiognomy of his very young lover MarieThérèse Walter in a series of portraits dated 1926, as for instance Bust of a Young Girl (see yopp26o04) and Head of Woman (see yopp26-013).

\section{Evolution of the Medusa iconotype}

Marie-Thérèse's unfolded face would evolve towards increasingly outlined features (compare the previous two artworks with Head of Woman in Grey and Red over an Ocher Background, see yopp26-003, and Sitting Woman, see yopp26-017), finally arriving to the schematic version of the iconotype Medusa, usually represented as a bust or head. This is well illustrated by the following series of artworks, all of them dated 1927: Head of Woman (see yopp27-107), Head over a Red Background (see yopp27-113), Woman on an Armchair (see yopp27-118), and Asleep Woman on an Armchair (see yopp27-141). This is also the case of two colourful versions of Woman on an Armchair (see yopp27-010 and yopp27-011).

Medusa appears linked to the Harlequin iconotype in some cases and to the shadow profile in other cases. Furthermore, in a piece of work dated 1927 the shadow profile appears associated to the acronyms linking Picasso with his young lover (see yopp27-109). Therefore, it seems that there is a (re)emergence of the shadow profile as well as connections with the Harlequin iconotype in the evolution of the Medusa iconotype. For instance, see three different works entitled Harlequin (see yopp26-o66, yopp27-131 and yopp27-139), two other works entitled Head (see yopp28-145 and yopp28-146), and a Figure (see yopp28-125). According to Prof. Carmona, all this can be interpreted as follows: Picasso would be linking Medusa to one of his main alter egos, namely, Harlequin, and he would be summoning the devastating effect of the Gorgon on his

\footnotetext{
${ }^{2}$ In Spanish in the original reference (see [4]). Translated to English by the author of this essay.

${ }^{3}$ Dryads were nymphs of the woods that formed an only being with trees.
} 
own personality identified with its shadow profile. In this context, Medusa would mean and contain the annihilation (or at least the impasse) of the creative impulse. The trail of this evolving face of Medusa can be also found out in Nude over a White Background (see yopp27-054), Figure (see yopp27-142), Face of Woman (see yopp28-134) and Figure (see yopp28-144).

In two key artworks of the series, both entitled Figure and Profile (see yopp27-oo6 and yopp28-006), Picasso redirects the image of Medusa through the rhetoric device of the picture within a picture. In such a way, Medusa becomes a representation. In 1928 Medusa enters the artist's workshop. This is the case of The Painter and His Model (see yopp28-oo1), The Workshop (see yopp28-104), Painter with Palette in front of an Easel (see yopp28-114), The Painter and His Model (see yopp28-116) and The Painter in His Workshop (see yopp28-122). In these pieces the terrifying Gorgon supersedes the artist, or better Medusa overlaps with him. This evolved representation of Medusa in the role of the artist or as a lookalike of the artist could be understood as the fear to the artist's annihilation from his own inside.

In a last turn of the screw, Medusa becomes a recumbent, nude model on an armchair or a bed, as in the case of Recumbent Nude (see yopp29-o71). Now the monster would allude to the cancellation of the erotic drive and to the distressing presence of the death drive. And in such a way, the end of the cycle arrives with a great painting, as so many times Picasso uses to close his creative cycles. The final and definitive pictorial representation of the evolving Picassian Medusa was dated May 5th, 1929 and entitled as the Great Nude on a Red Armchair (see yopp29-063).

\section{Translation of the Medusa iconotype to sculpture and the trail of Medusa in the artistic work of Picasso during the period 1930-1937}

Although much less frequent than in his drawings and paintings, in the years 1928-1929 Picasso translates several times the Medusa iconotype to a three-dimensional, sculptural representation. This is the case of Head (see yopp28-109), and Head of Woman (see yopp29-073).

The trail of Medusa can be found in the 1930 masterpiece Crucifixion (see yopp30-oo1), as well as in a diversity of artworks dated 1930-1037, including those that recreated the issue of the death of Marat. This is the case of Woman with Stylet (see yopp31-oog), The Murder (see yopp34020) and Blind Minotaur Driven by a Little Girl (see yopp34-oog). And it is also the case of other artpieces, as Bather Sitting by the Sea (see yopp3o-0o2) and Woman Asleep in an Armchair (see yopp32-023). Finally, the trail of Medusa is still present in one of the major and most significant masterworks made by Picasso: Guernica (see yopp37-oo1).

\section{Concluding remarks}

The use of the iconotype Medusa as introduced by Prof. Eugenio Carmona helps us to understand the ever-evolving, folding, and unfolding, changing and complex art of Pablo Picasso in the particularly dark period comprised between two of his masterpieces, The Three Dancers (1925) and Crucifixion (1930). Much more reflective effort and research will be required in the future to approach the Picassian insatiable and mumberless hunger for being ever the same and other. The cursive belongs to The Book of Disquiet by Fernando Pessoa but can be used to characterize the artistic pulse of Picasso. 


\section{Acknowledgments}

Thanks are due to Prof. Eugenio Carmona for his masterful teachings on the subject Picasso and the Spanish Art of XXth Century.

\section{References}

Bozal, V. La dríada. [In Spanish]. In Picasso; Jiménez-Blanco, M.D., Solana, G., Eds.; Fundación Cultural Mapfre Vida: Madrid, Spain, 2002; pp. 43-6o.

Carmona, E. Iconografía del desasosiego. Picasso y la fábula de Medusa (1925-1937). [In Spanish]. Anthropos 1994, 6, 55-58.

Carmona, E. Picasso \& Medusa. Iconografías del desasosiego. 1927-1929. [In Spanish]. In Picasso; JiménezBlanco, M.D., Solana, G., Eds.; Fundación Cultural Mapfre Vida: Madrid, Spain, 2002; pp. 113-145.

Mallen E. On-Line Picasso Project.Available onlne: https://picasso.shsu.edu (last accessed on $27^{\text {th }}$ August 2016).

Moreno, A. Sueño y pesadilla. [In Spanish]. In El espejo y la máscara. El retrato en el siglo de Picasso-Guía didáctica; Moreno, A., Ed.; Fundación Colección Thyssen-Bornemisza: Madrid, Spain, 2007; pp. 24-27.

Stoichita, V.I. Breve historia de la sombra; Siruela: Madrid, Spain, 1999. 